\title{
ANALISIS KEARIFAN LOKAL MASYARAKAT BENGKULU \\ DALAM FESTIVAL TABOT BERDASARKAN RECEPTIO IN COMPLEXU THEORY
}

\author{
Sandra Megayanti \\ Fakultas Hukum Universitas Bengkulu \\ Jl. Wr. Supratman, Kandang Limun, Kec. Muara Bangka Hulu, Sumatera, Bengkulu 38371 \\ Email: megayantisandra@gmail.com \\ Arie Elcaputera \\ Fakultas Hukum Universitas Bengkulu \\ Jl. Wr. Supratman, Kandang Limun, Kec. Muara Bangka Hulu, Sumatera, Bengkulu 38371 \\ Email: arieelcaputera.ae@gmail.com
}

\begin{abstract}
Abstact : Local wisdom is part of the field of community life that reflects the cultural values. Every region in Indonesia has its own local wisdom, some of which is still preserved today. For the example, one of the local wisdoms in Bengkulu community, Tabot festival which is routinely held every year that it has religious values and local culture. But in its implementation, there are things that are debated, especially regarding the tendency for practices that are contrary with the values of Islam. Therefore, in this article will discuss about the local wisdom of the Bengkulu people in the Tabot Festival and the concept of the Tabot Festival based on the Receptio In Complexu theory.
\end{abstract}

Keywords: Local Wisdom; Tabot Festival; Receptio In Complexu Theory.

\begin{abstract}
Abstrak: Kearifan lokal merupakan bagian dari lapangan hidup masyarakat yang mencerminkan nilai-nilai kebudayaan yang terdapat didalamnya. Setiap daerah di Indonesia memiliki kearifan lokalnya masing-masing yang sebagian diantaranya masih terus dilestarikan hingga saat ini. Salah satu kearifan lokal masyarakat Bengkulu misalnya festival tabot yang rutin diselenggarakan setiap tahunnya yang didalamnya terdapat nilai-nilai religius maupun kebudayaan setempat. Namun dalam penyelenggaraannya, terdapat hal-hal yang diperdebatkan khususnya mengenai kecenderungan adanya praktik-praktik yang bertentangan dengan ajaran agama Islam. Oleh karena itulah, selanjutnya dalam artikel ini akan membahas mengenai kearifan lokal masyarakat Bengkulu dalam festival tabot dan konsep festival tabot berdasarkan teori Receptio In Complexu.
\end{abstract}

Kata Kunci: Kearifan Lokal; Festival Tabot; Teori Receptio In Complexu. 


\section{Pendahuluan}

Dikutip dari pendapat Mac Iver, salah satu fungsi negara dalam sistem negara modern adalah mengatur hubungan-hubungan manusia yang terjadi dalam masyarakat, memberikan pembatasan atau keleluasaan, serta memenuhi kebutuhan masyarakatnya, karena itu peraturan perundang-undangan dibentuk oleh negara dan digunakan untuk mengatur tata tertib masyarakat ${ }^{1}$. Hukum pada dasarnya adalah alat untuk menciptakan ketertiban dalam masyarakat. Mayarakat dalam suatu negara perlu diberi rambu-rambu, tidak saja tentang bagaimana cara berinteraksi antara sesama manusia dalam kelompok masyarakat, tetapi juga antara manusia dengan sumber daya alam yang ada dalam penguasaan negara, dalam memenuhi kebutuhan hidupnya. Sebagaimana termuat dalam pasal 33 ayat (3) UUD Negara Republik Indonesia Tahun 1945 yang menyatakan bahwa bumi, air, dan kekayaan alam lainnya, dikuasai oleh negara untuk dipergunakan sebesar-besarnya bagi kemakmuran rakyat. Oleh karena itu, negara mengatur penggunaan listrik, air, mengatur penggalian bahan tambang (minyak, batubara, nikel, emas, dan lain-lain), agar dapat merata dimanfaatkan oleh masyarakat. Tujuan lainnya adalah agar masyarakat memanfaatkan sumber daya alam dan lingkungan dengan bijaksana,

\footnotetext{
${ }^{1}$ Marhaeni Ria Siombo. Hukum Lingkungan dan Pelaksanaan Pembangunan Berkelanjutan di Indonesia. Jakarta: PT. GramediaPustakaUtama , 2012, hlm. 39

menjaga kelestariannya, tidak mencemari lingkungan, sehingga sumber daya alam tersebut juga dapat dinikmati oleh generasi yang akan datang. Tuhan menciptakan segala sesuatu, bumi dan segala isinya, tidak untuk satu generasi tetapi untuk semua manusia di semua generasi ${ }^{2}$.

Hukum mempunyai tujuan untuk menjamin adanya kepastian hukum dalam masyarakat dan hukum itu harus pula bersendikan pada keadilan yaitu asas-asas keadilan dari masyarakat ${ }^{3}$. Didalam skripsi Mustafa Kemal Ramadhan, disebutkan bahwa Locke seperti dikutip Huijbers berpendapat "masyarakat adalah lapangan hidup di mana individu-individu dapat mewujudkan hak-hak dan kebebasan asli mereka". Sedangkan menurut Machmud, lingkungan hidup adalah "segala benda, kondisi, keadaan dan pengaruh yang terdapat dalam ruangan yang kita tempati dan mempengaruhi hal yang hidup termasuk kehidupan manusia"4. Kearifan lokal merupakan bagian dari lapangan hidup masyarakat yang mencerminkan nilai-nilai kebudayaan yang terdapat didalamnya.

${ }^{2}$ Marhaeni RiaSiombo. Ibid. hlm. 41

${ }^{3}$ C.S.T. Kansil dan Christine S.T. Pemgantar Ilmu Hukum Indonesia. Jakarta : PT.RinekaCipta, 2011, hlm.36

${ }^{4}$ Skripsi Mustafa Kemal Ramadhan , Implementasi Keterlibatan Masyarakat Dalam Analisis Mengenai Dampak Lingkungan Hidup (Studi Yuridis Sosiologis Pada Masyarakat Terkena Dampak Di Kota Semarang), Fakultas Hukum Universitas Semarang, 2015, hlm.21 diakses via : http://lib.unnes.ac.id/22148/1/8111411237-s.pdf pada tanggal 18 September 2019 
Salah satu kearifan lokal yang terdapat di Indonesia dapat kita lihat di Kota Bengkulu, dimana masyarakat Bengkulu rutin setiap tahunnya menggelar festival Tabot yang didalamnya terdapat nilai-nilai religius maupun kebudayaan setempat. Namun, didalam pelaksanaannya terdapat hal-hal yang diperdebatkan khususnya mengenai kecenderungan adanya praktik-praktik yang bertentangan dengan ajaran agama Islam, mengingat mayoritas masyarakat Bengkulu merupakan pemeluk agama Islam. Hal ini sebagaimana dikemukakan oleh salah satu ustadz di Bengkulu yaitu Ustadz Amri yang pernyataannya didukung oleh Pengurus Ikatan Masjid Indonesia (IKMI) Bengkulu, $\mathrm{H}$. Hambali Nawawi.H. Hambali Nawawi dengan tegas mengatakan, proses ritual Tabot mengandung unsur syirik. Diantaranya proses duduk penja, mengambil tanah, bakar kemenyan di kuburan yang dihormati."Prosesnya banyak yang mengandung syirik. Contoh, mengambil tanah, lalu dibungkus kain, lalu didoakan, itu bukanlah ajaran Islam. Begitupun dengan ziarah ke makam membawa kemenyan. Ajaran Islam tidak pernah mengajarkan berziarah membakar menyan ${ }^{5}$. Alasan-alasan tersebutlah diantaranya yang menjadi perdebatan mengenai pelaksanaan festival Tabot di

${ }^{5}$ Nahi Munkar, Ramai, Khutbah TentangTabot Berbau Syiah dan Syirik di Bengkulu, diakses via: https://www.nahimunkar.org/ramai-khutbah-tentangtabot-berbau-syiah-dan-syirik-di-bengkulu/ pada tanggal 18 September 2019
Bengkulu, jelas hal ini menjadi suatu permasalahan, khususnya bagi masyarakat Bengkulu yang mayoritas menganut ajaran agama Islam, mengingat tidak sedikit muslim maupun muslimah kota Bengkulu yang mengambil bagian dari festival Tabot yang diadakan setiap tahunnya. Berdasarkan penjelasan diatas, maka penulis tertarik untuk membahas permasalahan tersebut dalam karya tulis ini yang berjudul Analisis Yuridis Tentang Analisis Kearifan Lokal Masyarakat Bengkulu Dalam Festival Tabot Berdasarkan Receptio In Complexu Theory.

\section{Pembahasan}

\section{Kearifan lokal masyarakat Bengkulu} dalam Festival Tabot

Kearifan lokal merupakan suatu warisan budaya dimana nilai-nilai yang ada dapat dilihat pada tradisi dan kebiasaan suatu masyarakat, seperti gotong royong, rela berkorban, saling menghormati dan sikap toleransi. Dari hal tersebut, ini akan menjadi suatu karakter bagi masyarakat yang menanamkan nilai-nilai tersebut dalam kehidupan sosial ${ }^{6}$. Salah satu kearifan lokal yang ada di masyarakat kota Bengkulu dapat dilihat dalam festival Tabot yang rutin diselenggarakan setiap tahunnya.

\footnotetext{
${ }^{6}$ MagdaliaAlfian, "Potensi Kearifan Lokal dalam Pembentukan Jati Diri dan Karakter Bangsa”, Makalah dalam Seminar Tentang The 5th Internasional Conference on Indonesian Studies: "Ethnicity and Globalization", diselenggarakanoleh ICSSIS (International Conference \& Summer School on Indonesian Studies) FakultasIlmu Pengetahuan BudayaUniversitas Indonesia, Yogyakarta, 13-14 Jun 2013, hlm. 424
} 

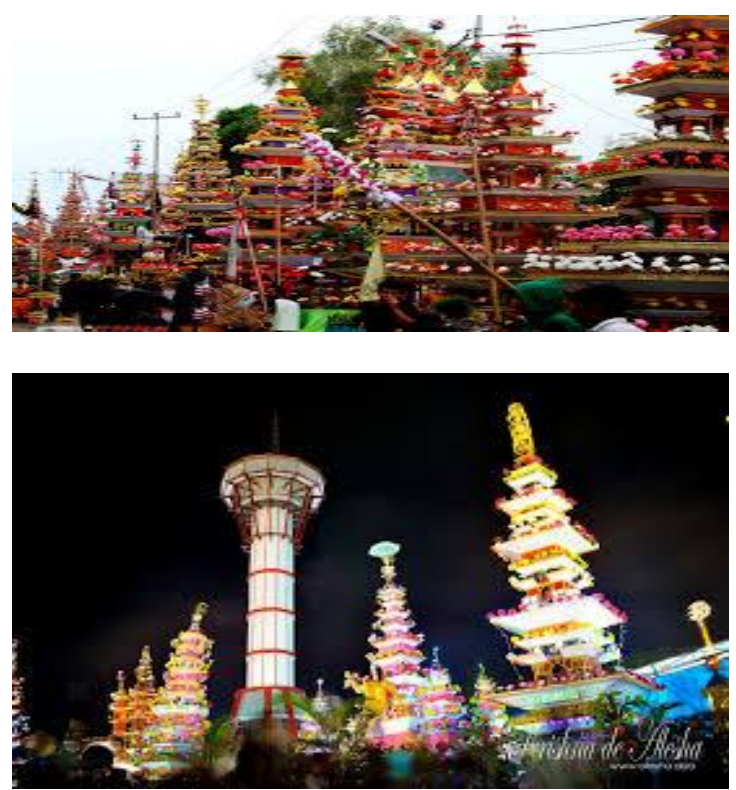

Tabot adalah upacara tradisional masyarakat Bengkulu, yang bertujuan untuk mengenang kisah kepahlawanan dan kematian cucu Nabi Muhammad S.A.W., Saidina Hassan bin Ali dan Saidina Hussein bin Ali dalam peperangan dengan pasukan Ubaidillah bin Zaid di padang Karbala, Iraq pada tanggal 10 Muharam 61 Hijriah bersamaan dengan 618 Masehi. Perayaan Tabot di Bengkulu pertama kali dilakukan oleh Syeikh Burhanuddin yang lebih dikenal sebagai Imam Senggolo pada tahun 1685. Syeikh Burhanuddin (Imam Senggolo) telah menikah dengan wanita Bengkulu kemudian anak mereka, cucu mereka dan keturunan mereka disebut sebagai keluarga Tabot. Upacara ini dilaksanakan dari tanggal 1 hingga 10 Muharram (berdasarka n kalender Islam Hijriah) pada setiap tahun.

Pada awalnya, inti dari upacara Tabot adalah untuk mengenang usaha pemimpin Syiah dan kaumnya dalam mengumpulkan potongan tubuh Husein, mengarak dan memakamnya di Padang Karbala. Istilah Tabot berasal dari kata Arab Tabut yang secara harfiah berarti "kotak kayu" atau "peti". Dalam Al-Qur'an kata Tabot telah dikenal sebagai sebuah peti yang berisikan kitab Taurat. Bani Israil di masa itu dipercayai bahwa mereka akan mendapatkan kebaikan bila Tabot ini muncul dan berada di tangan pemimpin mereka. Sebaliknya mereka akan mendapatkan malapetaka bila benda itu hilang. Tidak ada catatan tertulis sejak kapan upacara Tabot mulai dikenali di Bengkulu. Namun, diduga kuat tradisi yang berangkat dari upacara berkabung para penganut paham Syiah ini dibawa oleh para tukang yang membangun Benteng Marlborought (1718-1719) di Bengkulu. Para tukang bangunan tersebut, didatangkan oleh Inggris dari Madras dan Benggala di bahagian selatan India yang kebetulan merupakan penganut Islam Syiah. Para pekerja yang merasa serupa dan cocok dengan tatahidup masyarakat Bengkulu, dipimpin oleh Imam Senggolo atau Syeikh Burhanuddin, memutuskan tinggal dan mendirikan pemukiman baru yang disebut Berkas, sekarang dikenali dengan nama Kelurahan Tengah Padang. Tradisi yang dibawa dari Madras dan Bengali diwariskan kepada keturunan mereka yang telah berasimilasi dengan masyarakat Bengkulu asli dan menghasilkan keturunan 
yang dikenal dengan sebutan orangorang Sipai.

Tradisi berkabung yang dibawa dari negara asalnya tersebut mengalami asimilasi dan akulturasi dengan budaya setempat, dan kemudian diwariskan dan dilembagakan menjadi apa yang kemudian dikenali dengan sebutan upacara Tabot. Upacara tabot ini semakin meluas dari Bengkulu ke Painan, Padang, Pariaman, Maninjau, Banda Aceh, Meulaboh dan Singkil. Namun dalam perkembangannya, kegiatan Tabot telah banyak menghilang di banyak tempat, hingga pada akhirnya hanya terdapat di dua tempat, yaitu di Bengkulu dengan nama Tabot dan di Pariaman, Sumatera Barat (masuk sekitar tahun 1831) dengan sebutan Tabuik. Keduanya sama, namun cara pelaksanaannya agak berbeda. Pada awalnya upacara Tabot (Tabuik) digunakan oleh orang-orang Syiah untuk mengenang kematian Saidina Husein bin Ali bin Abi Thalib, namun sejak orangorang Sipai bebas dari pengaruh paham Syiah Muslim dan ramai dari mereka berpindah kepada paham Sunni Muslim , upacara ini dilakukan hanyalah sebagai suatu kewajiban keluarga, yakni untuk memenuhi wasiat leluhur keturunan mereka. Belakangan ini, selain untuk melaksanakan wasiat leluhur, upacara ini juga turut mengundang penyertaan dari masyarakat Sipai dalam pembinaan dan pengembangan budaya daerah Bengkulu setempat.

Kondisi sosial budaya masyarakat, nampaknya juga menjadi penyebab munculnya perbedaan dalam tata cara pelaksanaan upacara Tabot. Di Bengkulu misalnya, $\quad$ Tabot 17 menunjukkan kepada jumlah keluarga awal yang melaksanakan Tabot, sedangkan di Pariaman hanya terdiri dari 2 jenis Tabot (Tabuik) iaitu Tabuik Subarang dan Tabuik Pasa. Tempat pembuangan Tabot (Tabuik) antara Bengkulu dan Pariaman juga berbeda. Pada awalnya Tabot di Bengkulu di buang ke laut sebagaimana di Pariaman Sumatera Barat. Namun, pada perkembangannya, Tabot di Bengkulu dibuang di rawa-rawa yang berada di sekitar pemakaman umum yang dikenali dengan nama makam Karbela yang diyakini sebagai tempat dimakamnya Imam Senggolo atau Syeikh Burhanuddin. Belakangan ini juga, banyak kritikan dari berbagai elemen masyarakat terhadap pelaksanaan upacara Tabot. Satu hal yang paling mendasar dari semua kritikan tersebut adalah berubahnya fungsi upacara Tabot dari ritual bernuansa keagamaan menjadi sekadar festival kebudayaan belaka. Ini nampaknya disebabkan oleh kenyataan bahawa yang melaksanakan upacara Tabot adalah orang-orang bukan Syiah. 
Untuk melaksanakan upacara Tabot, ada beberapa peralatan yang harus dipersiapkan, diantaranya adalah ${ }^{7}$ :

a. Pembuatan Tabot

Kelengkapan alat untuk membuat Tabot antara lain: bambu, rotan, kertas karton, kertas mar-mar, kertas grip, tali, pisau ukir, alat-alat gambar, lampu senter, lampu hias, bungakertas, bunga plastik dan sebagainya. Jumlah pembiayaan yang diperuntukkan untuk membuat Tabot adalah sekitar 5-15 juta rupiah.

b. Kenduri dan Sesaji

Bahan-bahan yang digunakan untuk membuat kenduri dan sesaji antara lain: beras ketan, pisang emas, tebu, jahe, dadih, gula aren, gula pasir, kelapa, ayam, daging, bumbu masak, kemenyan dan lain-lain.

c. Perlengkapan Musik Tabot

Alat-alat musik yang biasanya digunakan dalam upacara tabot adalah dol dan tessa. Dol terbuat dari kayu yang tengahnya dilubangi dan kemudian ditutup dengan menggunakan kulit lembu. Dol berbentuk seperti beduk. Garis tengahnya sekitar $70-125 \mathrm{~cm}$, dan alat pemukulnya berdiameter $5 \mathrm{~cm}$ dan panjangnya $\quad 30 \quad \mathrm{~cm}$. Cara menggunakannya dengan cara dipukul-

\footnotetext{
${ }^{7}$ Wikipedia Ensiklopedia Bebas, Tabot, diakses via: https://ms.wikipedia.org/wiki/Tabot pada tanggal 18 September 2019

pukul. Sedangkan Tessa berbentuk seperti rebana, terbuat dari tembaga, besi plat atau aluminium, dan juga bisa dari kuali yang permukaannya ditutup dengan kulit kambing yang telah dikeringkan.

d. Kelengkapan lainnya

Perlengkapan-perlengkapan lain yang harus dipersiapkan pada setiap unit Tabot adalah: Bendera merah putih ukuran rumah tangga berikut tiangnya, bendera panji-panji yang berwarna hijau atau biru yang ukurannnya lebih besar dari bendera merah-putih, bendera putih yang ukurannnya sama dengan panil (beserta tiangnya), tombak bermata ganda diujungnya digantung, duplikat pedang zufikar (pedang Rasulullah) dengan ukuran mini.

Sementara itu tahapan-tahapan upacara Tabot adalah sebagai berikut ${ }^{8}$ :

a. Mengambik tanah (mengambil tanah)

Tanah yang diambil harus mengandung unsur-unsur magis oleh karena itu harus diambil dari tempat keramat. Di Bengkulu, hanya ada dua tempat yang dianggap keramat yaitu di Keramat Tapak Padri yang terletak di tepi laut tidak jauh dari Benteng Marlborough di sudut kanan Pelabuhan Laut Bengkulu dan Keramat

${ }^{8}$ Wikipedia Ensiklopedia Bebas, Tabot, diakses via: https://ms.wikipedia.org/wiki/Tabot pada tanggal 18 September 2019 
Anggut yang terletak di pemakaman umum dekat Tugu Hamilton, tidak jauh dari Pantai Nala. Upacara ini berlangsung pada malam tanggal 1 Muharam, sekitar pukul 22.00 WIB.

Tanah yang diambil disimpan di Gerga (pusat kegiatan/markas kelompok Tabot bersangkutan), dibentuk seperti boneka manusia dan dibungkus dengan kain kafan putih, lalu diletakkan di Gerga. Gerga tertua di Bengkulu hanya ada dua, yaitu Gerga Berkas dan Gerga Bangsal. Keduanya telah direnovasi dan kini berwujud bangunan permanen.

Di kedua tempat tersebut, mereka memberikan beberapa sesajen yang berupa: bubur merah dan bubur putih, gula merah, sirih tujuh subang, rokok nipah sebanyak tujuh batang, kopi pahit sebanyak satu cangkir, air serbat satu cangkir, dadih (susu sapi murni yang mentah) satu cangkir, air cendana satu cangkir, air dan selasih satu cangkir.

b. Duduk Penja (mencuci jari-jari)

Penjaadalah benda yang terbuat dari kuningan, perak atau tembaga yan $\mathrm{g}$ berbentuk telapak tangan manusia lengkap dengan jari-jarinya, oleh karena itulah penja disebut juga dengan jari-jari. Menurut keluarga Sipai, Penja adalah benda keramat yang mengandung unsur magis. Ia harus dicuci dengan air limau setiap tahunnya. Upacara mencuci penja ini disebut duduk Penja, yang dilaksanakan pada tanggal 5 Muharram sekitar pukul 16.00 WIB.

Pada acara Penja ini, peralatan yang dibutuhkan adalah: air kembang, air limau nipis, sesajen, dan penja yang akan dicuci. Sesajen yang dipersiapkan terdiri: nasi kebuli sebanyak satu porsi, emping beras sebanyak satu piring, pisang emas satu sisir, tebung satu potong, kopi pahit satu gelas, air serobat satu gelas, dan dadih satu gelas.

c. Menjara (mengandun)

Menjara adalah berkunjung atau mendatangi kelompok lain untuk beruji/bertanding $d o l$, sejenis beduk yang terbuat dari kayu yang dilubangi tengahnya serta ditutupi dengan kulit lembu. Kegiatan ini dilaksanakan tepatnya yaitu pada tanggal 6 dan 7 Muharram mulai pukul 20.00 atau 23.00 WIB. Pada tanggal 6 Muharram, kelompok Tobat Bangsal mendatangi kelompok Tobat Barkas sedangkan pada tanggal 7 Muharram kelompok Tobat Barkas mendatangi kelompok Tobat Bangsal. Kegiatan ini berlansung dihalaman terbuka yang disediakan oleh masing-masing kelompok. 
d. Meradai (mengumpulkan dana)

Meradai adalah pengambilan dana oleh Jola (bahasa Melayu artinya orang yang bertugas mengambil dana untuk kegiatan kemasyarakatan) yang terdiri dari anak-anak berusia 10-12 tahun. Acara ini dilakukan pada siang hari tanggal 6 Muharram diantaranya pukul 07.00-17.00 WIB. Lokasi pengambilan dana biasanya sudah disepakati bersama oleh masing-masing kelompok Tabot. Peralatan yang dibutuhkan diantaranya

adalah: bendera panji, tombak bermata ganda, tas, atau kambut, karung gandum, dan tessa.

e. Arak Penja (mengarak jari-jari)

Arak Penja atau arak jari-jari merupakan acara mengarak jari-jari yang diletakkan di dalam Tabot dengan di jalan-jalan utama di kota Bengkulu. Kegiatan ini dilaksanakan pada malam ke-8 dari bulan Muharram, yaitu sekitar pukul 19.00 WIB dan berakhir sekitar pukul 21.00 WIB. Bahan-bahan yang digunakan sebagai bahan sesajen adalah: nasi kebuli 1 porsi, kopi pahit 1 gelas, air serobat 1 gelas, telur dadar 1 buah, lauk pauk 7 piring (7 macam jenis lauk).

f. Arak Seroban (mengarak Sorban)

Arak Serban merupakan acara mengarak Penja ditambah dengan Serban (Sorban) putih dan diletakkan pada Tabot Coki (Tabot Kecil). Tabot Coki ini dilengkapi dengan bendera/panji-panji berwarna putih dan hijau atau biru yang bertuliskan nama "Hasan dan Husain" dengan kaligrafi Arab yang indah. Kegiatan ini diadakan pada malam ke-9 Muharram sekitar pukul 19.00-21.00 WIB. Sebagaimana namanya, maka peralatan yang dibutuhkan dalam acara ini adalah Tabot dan seroban. Selain itu, juga dibutuhkan kain khusus dan Tabot Coki (kursi kerajaan/tahta).

g. Gam (tenang / berkabung)

Satu di antara tahapan upacara Tabot yang harus ditaati adalah "gam". Gam adalah waktu yang tidak boleh ada kegiatan apapun. Gam berasal dari kata "ghum" yang berarti tertutup atau terhalang. Tanggal 9 Muharram merupakan masa gam ini, yakni sejak pukul 07.00 hingga pukul 16.00 WIB, di mana pada waktu tersebut semua kegiatan yang berkaitan dengan upacara Tabot termasuk membunyikan dol dan tessa tidak boleh dilakukan. Jadi masa gam dapat juga disebut masa tenang.

h. Arak Gedang (taptu akbar)

Pada 9 Muharram malam, sekitar pukul 19.00 WIB dilaksanakan ritual pelepasan Tabot Besanding di gerga (markas) masing-masing. Selanjutnya dilanjutkan dengan arak 
gedang yakni grup Tabot berarak dari markas masing-masing menempuh rute yang ditentukan. Kemudian mereka akan bertemu sehingga membentuk arak gedang (pawai akbar). Arakarakan ini menjadi ramai karena menyatunya grup-grup Tabot, grupgrup hiburan, para pendukung masingmasing serta masyarakat. Acara ini berakhir sekitar pukul 20.00 WIB. Akhir dari acara arak gedang ini adalah seluruh Tabot dan grup penghibur berkumpul di lapangan Merdeka Bengkulu (Sekarang: Lapangan Tugu Propinsi). Tabot dibariskan bershaf istilah lokal disandingkan, karenanya acara ini dinamakan Tabot Besanding. Peralatan yang dibutuhkan dalam kegiatan tabot besanding ini adalah gerobak. Gerobak ini digunakan untuk mengangkut Tabot ke tempat Tabot dikumpulkan.

i. Tabot Tebuang (Tabot terbuang)

Acara terakhir dari rangkaian upacara Tabot adalah acara Tabot tebuang yang diadakan pada tanggal 10 Muharram. Pada pukul 09.00 WIB seluruh Tabot telah berkumpul di lapangan Merdeka dan telah disandingkan sebagaimana malam Tabot besanding. Grup hiburan telah berkumpul pula di sini dan menghibur para pengunjung yang hadir di waktu itu. Pada sekitar pukul 11.00 arak- arakan Tabot bergerak menuju ke Padang Jati dan berakhir di kompleks pemakaman umum Karabela. Tempat ini menjadi lokasi acara ritual Tabot tebuang karena di sini dimakamkan Imam Senggolo (Syekh Burhanuddin) pelopor upacara Tabot di Bengkulu.

Pada sekitar pukul 12.30 WIB acara Tabot Tebuang di makam Senggolo tersebut. Karena dipandang bernilai magis, acara ini hanya bisa dipimpin oleh Dukun Tabot yang tertua. Selesai acara ritual di atas, barulah bangunan Tabot dibuang ke rawa-rawa yang berdampingan dengan komplek makam tersebut. Dengan terbuangnya Tabot pada sekitar pukul 13.30 WIB, maka selesailah seluruh rangkaian upacara Tabot dimaksud.

Setiap tindakan dalam upacara Tabot selalu diawali dengan pembacaan Basmalah dan doa-doa. Doa-doa tersebut diantaranya adalah ${ }^{9}$ :

a. Doa kubur;

b. Doa mohon selamat dan ampunan atas arwah orang-orang Muslim di dunia;

c. Bacaan tasbih;

d. Salawat ulul 'azmi;

e. Salawat Wasilah dan lainnya.

Secara umum, ada dua nilai yang terkandung dalam pelaksanaan upacara Tabot, yaitu: nilai Agama (sakral), sejarah,

${ }^{9}$ Wikipedia Ensiklopedia Bebas, Tabot, diakses via: https://ms.wikipedia.org/wiki/Tabot pada tanggal 18 September 2019 
dan sosial. Nilai-nilai Agama (sakral) dalam upacara Tabot diantaranya adalah: Pertama, proses mengambik tanah mengingatkan manusia akan asal penciptaannya. Kedua, terlepas dari adanya pandangan bahwa ritual tabot mengandung unsur penyimpangan dalam akidah, seperti penggunaan mantera-mantera dan ayat- ayat suci dalam prosesi mengambik tanah, namun esensinya adalah untuk menyadarkan kita bahwa keberagamaan tidak bisa dilepaskan dari nilainilai budaya setempat.

Dan ketiga, pelaksanaan upacara Tabot merupakan perayaan untuk menyambut tahun baru Islam.

Nilai sejarah yang terkandung dalam budaya tabot adalah sebagai manifestasi kecintaan dan untuk mengenang wafatnya cucu Nabi Muhammad SAW., yakni Hassan dan Hussein bin Ali yang terbunuh di Padang Karbala dan juga sebagai ekspresi permusuhan terhadap keluarga Bani Umayyah pada umumnya dan khususnya pada Yazid bin Muawiyah, Khalifah Bani Umayyah yang memerintah waktu itu, beserta Gabenor 'Ubaidillah bin Ziyad yang memerintahkan penyerangan terhadap Hussain bin 'Alî beserta askarnya. Adapun nilai sosial yang terkandung di dalamnya, antara lain: mengingatkan manusia akan praktik penghalalan segala cara untuk menuju puncak kekuasaan dan simbolisasi dari sebuah keprihatinan sosial.

Banyak nilai-nilai kebijaksanaan yang dapat digali dan dijadikan landasan untuk mengarungi kehidupan, tetapi jika tidak disikapi dengan bijaksana, maka upacara Tabot akan menjadi sekedar festival budaya yang kehilangan makna dasarnya. Meriah dalam pelaksanaan (festival) tapi kehilangan spiritnya $^{10}$. Festival Tabot sebagaimana dijelaskan diatas merupakan salah satu bentuk atau wujud dari kearifan lokal masyarakat Bengkulu.

2. Konsep Festival Tabot berdasarkan Receptio in Complexu Theory

Teori receptio in complexu dikemukakan oleh Mr. W.C. van den Berg, Guru Besar di Delf dan Penasihat bahasabahasa Timur dan Hukum Islam pada Pemerintah kolonial Belanda. Inti dari teori ini adalah:"Selama bukan sebaliknya dapat dibuktikan, menurut ajaran ini hukum pribumi ikut agamanya, karena jika memeluk agama harus juga mengikutihukum agama itu dengan setia”. Tegasnya menurut teori ini, jika suatu masyarakat itu memeluk suatu agama tertentu, maka hukum adat masyarakat yang bersangkutan adalah hukum agama yang dipeluknya itu. Jika terdapat hal-hal yang menyimpang dari hukum agama yang

\footnotetext{
${ }^{10}$ Wikipedia Ensiklopedia Bebas, Tabot, diakses via: https://ms.wikipedia.org/wiki/Tabot pada tanggal 18 September 2019
} 
dipeluknya, maka hal ini dianggapsebagai suatu “perkecualian/penyimpangan" dari hukum agama yang telah"in complexu gerecipieerd"(diterima secara keseluruhan).Dengan berlandas pada teori yang dikemukakannya itu, maka van den Berg menggambarkanhukum adat itu sebagai hukum yang terdiri hukum agama dan penyimpangan penyimpangannya ${ }^{11}$.

L.W.C. van den Berg (1845-1927) merupakan sarjana Belanda pertama yang diangkat sebagai penasehat khusus Pemerintah Kolonial Belanda dalam bidang Bahasa-Bahasa Timur dan Hukum Islam (eastern language and Islamic law), ditugaskan untuk menjawab pertanyaanpertanyaan para Pejabat Pemerintah Kolonial Belanda menyangkut ajaran Islam terkait dengan kehidupan sehari-hari umat Islam.Van den Berg bertugas di Indonesia (1870-1887), dengan teorinya Receptio in Complexu. Berdasarkan pengalamannya beberapa tahun di Indonesia dan khususnya ketika bertugas di Pengadilan Negeri Semarang, ia sampai kepada kesimpulan: penting untuk melakukan unifikasi hukum Islam di Indonesia. Ia kemudian mengusulkan agar kitab Minhaj alThalibin (dan terjemahan dia kedalam bahasa Perancis) dijadikan Undang-Undang Pengadilan Agama "yang digunakan

\footnotetext{
${ }^{11}$ SCRIBD, Teori Receptio in Complexu,

sebagai pedoman para hakim Pengadilan Agama di Indonesia ${ }^{12}$."

Hukum penduduk setempat (dan juga orang-orang Timur lainnya) sangat dipengaruhi dan ditentukan oleh agama yang dianut sejauh tidak ada bukti lain yang menolaknya. Sebab dengan menerima dan menganut suatu agama berarti sekaligus juga menerima aturan hukum dari agama yang dianutnya tersebut. Jika terdapat bukti yang sebaliknya atau "sebuah pengecualian" berupa atauran-aturan tertentu, maka pengecualian tersebut harus dipandang sebagai "deviasi" dari hukum agama yang telah diterima secara complexu.

Hukum Islam dipandang sebagai hukum yang hidup dan berlaku (the living law) bagi umat Islam. Teori ini didasarkan pada keyakinan Van den Berg bahwa "Islam telah diterima secara baik oleh sebagian besar umat Islam setempat." Teori Van den Berg ini kemudian diresmikan melalui Aturan Pemerintah Kolonial Belanda Nomor 152 tahun 1882. Van den Berg bukanlah orang pertama yang berpendapat bahwa hukum Islam adalah hukum yang berlaku bagi umat Islam di Indonesia. Pengakuan ini terlihat dalam beberapa kententuan yang terdapat pada Reglement op het beleid der

\footnotetext{
${ }^{12}$ Jurnal Pamel Kritis Konstruktif, L.W.C. van den Berg: Teori Receptio in Complexu, diakses via: https://agendapamel.wordpress.com/islamic-studies/l-wc-van-den-berg-teori-receptio-in-complexu/ pada tanggal 18 September 2019
} 
Regeering van Nederlandsch Indie(R.R.), Stbl. Nomor 129 tahun 1854 dan Nomor 2 tahun 1855, terutama pasal-pasal 75, 78, dan 109. Pada masa Daendels dan Raffles, hukum yang berlaku bagi umat Islam Indonesia adalah hukum Islam. Van den Berg adalah orang pertama yang merumuskannya dalam bentuk teori yang kemudian dikenal secara luas. Berdasarkan teori yang diajukan oleh Van den Berg, institusi keagamaan (Islam) yang telah ada dan berjalan pada masa sebelum penjajahan Belanda, seperti Pengadilan Agama, berlanjut terus di tengah-tengah masyakarat Islam, dan Van den Berg meneruskan hal tersebut dengan berupaya agar hukumhukum perkawinan dan kewarisan Islam direalisasikan secara baik oleh umat Islam dalam kehidupan sehari-hari ${ }^{13}$.

Selanjutnya kaitannya dengan konsep festival tabot di kota Bengkulu, maka berdasarakan teori receptio in complexu, dapat dilihat bahwasannya festival tabot merupakan festival dengan unsur-unsur keagamaan didalamnya disamping terdapat unsur-unsur budaya setempat yang telah menjadi ciri khas atau merupakan salah satu bagian dari bentuk atau wujud kearifan lokal masyarakat Bengkulu. Teori receptio in complexu yang menyebut hukum adat itu sebagai suatu hukum yang terdiri dari

\footnotetext{
${ }^{13}$ Jurnal Pamel Kritis Konstruktif, L.W.C. van den Berg: Teori Receptio in Complexu, diakses via: https://agendapamel.wordpress.com/islamic-studies/l-wc-van-den-berg-teori-receptio-in-complexu/ padatanggal 18 September 2019

hukum agama dan penyimpangan penyimpangannya menunjukkan bahwasannya kebiasaan-kebiasaan masyarakat yang telah menjadi suatu budaya yang dengan prosesnya "meresepsi" hukum agama pada akhirnya dapat diakui sebagai bagian dari hukum yang hidup dan berkembang dalam masyarakat walaupun sebenarnya apabila di tarik kembali kepada ajaran-ajaran agama yang sesungguhnya, tidak menutup kemungkinan terdapat halhal yang sebenarnya bertentangan dengan ajaran-ajaran agama.

Seperti dalam hal ini festival tabot yang merupakan kegiatan rutin yang setiap tahunnya diadakan di kota Bengkulu, jika kita analisis berdasarkan teori receptio in complexu, maka dapat terlihat bahwasannya dalam pelaksanaan festival tabot terdapat unsur-unsur keagamaan, dalam hal ini "meresepsi" ajaran agama Islam dan saya penulis secara pribadi dapat mengatakan selain ajaran agama Islam terdapat pula bentuk dari ajaran agama lainnya yaitu Hindu yang juga "diresepsi" didalamnya, seperti adanya "sesaji" atau "sesajen", kemudian bentuk-bentuk tabot yang menyerupai patung-patung yang mana didalam ajaran agama Islam tidak dikenal hal-hal demikian. Sementara itu ajaran agama Islam yang di "resepsi" dapat dilihat dari adanya do'a-do'a yang dipanjatkan selama berlangsungnya festival tabot maupun waktu pelaksanaannya yang jatuh 
bertepatan pada tahun baru Islam. Namun, yang harus digaris bawahi adalah menurut penulis secara pribadi, terdapat hal-hal yang sebenarnya tidak sesuai dengan ajaran agama Islam, sebagaimana telah dijelaskan sebelumnya, seperti adanya kepercayaan dalam proses tabot yaitu mengambil tanah yang mengandung unsur magis, kemudian penggunaan sesaji, membakar kemenyan, duduk penja dan hal-hal lainnya yang sebenarnya didalam ajaran agama Islam tidak dibenarkan, karena hal tersebut dapat membawa kita pada kesyirikan.

Selain berbicara mengenai unsur keagamaan didalam prosesnya, satu hal yang juga harus diperhatikan adalah masalah lingkungan, mengingat dalam prosesnya terdapat tahapan pembuangan tabot ke suatu tempat yang di keramatkan, dan hal tersebut pastinya akan berdampak pada lingkungan, oleh karena itu dalam hal ini jika kita berbicara mengenai lingkungan maka didalam ketentuan pasal 67 Undangundang Nomor 32 Tahun 2009 Tentang Perlindungan dan Pengelolaan Lingkungan Hidup diatur tentang kewajiban terhadap pemeliharaan lingkungan hidup bagi setiap orang yang dirumuskan sebagai berikut:

"Setiap orang berkewajiban memelihara kelestarian fungsi lingkungan hidup serta mengendalikan pencemaran dan/ atau kerusakan lingkungan hidup."

Selanjutnya, oleh karena pengelolaan lingkungan hidup merupakan upaya terpadu untuk melestarikan fungsi lingkungan yaitu yang meliputi kebijaksanaan, penataan, pemanfaatan, pengembangan, pemeliharaan, pemulihan, pengawasan dan pengendalian lingkungan hidup maka pengelolaan lingkungan hidup diselenggarakan dengan asas tanggung jawab negara, asas berkelanjutan, dan asas manfaat $^{14}$. Dari ketentuan peraturan perundang-undangan diatas, maka dapat dilihat bahwasannya, setiap orang memiliki kewajiban untuk menjaga, merawat dan memelihara lingkungan hidup, oleh karena itu walaupun setiap kegiatan atau acara yang merupakan salah satu bagian dari bentuk atau wujud kearifan lokal suatu daerah diadakan, masalah dampak lingkungan hidup yang mungkin akan ditimbulkan haruslah menjadi perhatian megingat kita sebagai warga negara mempunyai kewajiban menjaga lingkungan sebagaimana dimaksud dalam ketentuan peraturan perundang-undangan.

\section{Penutup}

Festival Tabot merupakan upacara tradisional masyarakat Bengkulu, yang bertujuan untuk mengenang kisah kepahlawanan dan kematian cucu Nabi Muhammad S.A.W, Saidina Hassan bin Ali dan Saidina Hussein bin Ali dalam peperangan dengan pasukan Ubaidillah bin

${ }^{14}$ Alvi Syahrin, Beberapa IsuHukum Lingkungan Kepidanaan, (Medan: PT. Sofmedia, 2009), hlm. 58 
AL-IMARAH: Jurnal Pemerintahan dan Politik Islam Vol. 4, No. 2, 2019

Zaid di padang Karbala, Iraq pada tanggal 10 Muharam 61 Hijriah bersamaan dengan 618 Masehi. Festival tabot dilaksanakan rutin setiap tahunnya di Kota Bengkulu dan hal tersebut telah menjadi bagian dari bentuk atau wujud kearifan lokal masyarakat Bengkulu.

Nilai-nilai yang terkandung dalam upacara Tabot diantaranya adalah: Pertama, proses mengambik tanah mengingatkan manusia akan asal penciptaannya. Kedua, terlepas dari adanya pandangan bahwa ritual tabot mengandung unsur penyimpangan dalam akidah, seperti penggunaan manteramantera dan ayat- ayat suci dalam prosesi mengambik tanah, namun esensinya adalah untuk menyadarkan kita bahwa keberagamaan tidak bisa dilepaskan dari nilainilai budaya setempat. Ketiga, pelaksanaan upacara Tabot merupakan perayaan untuk menyambut tahun baru Islam. Nilai sejarah yang terkandung dalam budaya tabot adalah sebagai manifestasi kecintaan dan untuk mengenang wafatnya cucu Nabi Muhammad SAW., yakni Hassan dan Hussein bin Ali.

Festival tabot merupakan festival dengan unsur-unsur keagamaan didalamnya disamping terdapat unsur-unsur budaya setempat yang telah menjadi ciri khas atau merupakan salah satu bagian dari bentuk atau wujud kearifan lokal masyarakat Bengkulu. Teori receptio in complexu yang menyebut hukum adat itu sebagai suatu hukum yang terdiri dari hukum agama dan penyimpangan penyimpangannya menunjukkan bahwasannya kebiasaan-kebiasaan masyarakat yang telah menjadi suatu budaya yang dengan prosesnya "meresepsi" hukum agama pada akhirnya dapat diakui sebagai bagian dari hukum yang hidup dan berkembang dalam masyarakat walaupun sebenarnya apabila di tarik kembali kepada ajaran-ajaran agama yang sesungguhnya, tidak menutup kemungkinan terdapat hal-hal yang sebenarnya bertentangan dengan ajaran-ajaran agama.

Seperti dalam hal ini festival tabot yang merupakan kegiatan rutin yang setiap tahunnya diadakan di kota Bengkulu, jika kita analisis berdasarkan teori receptio in complexu, maka dapat terlihat bahwasannya dalam pelaksanaan festival tabot terdapat unsur-unsur keagamaan, dalam hal ini "meresepsi" ajaran agama Islam dan saya penulis secara pribadi dapat mengatakan selain ajaran agama Islam terdapat pula bentuk dari ajaran agama lainnya yaitu Hindu yang juga "diresepsi” didalamnya, seperti adanya "sesaji" atau "sesajen", kemudian bentukbentuk tabot yang menyerupai patung-patung yang mana didalam ajaran agama Islam tidak dikenal hal-hal demikian. Sementara itu ajaran agama Islam yang di "resepsi" dapat dilihat dari adanya do'a-do'a yang dipanjatkan selama berlangsungnya festival tabot maupun waktu pelaksanaannya yang jatuh bertepatan pada tahun baru Islam. 


\section{Pustaka Acuan}

Alvi Syahrin, Beberapa Isu Hukum Lingkungan Kepidanaan, (Medan: PT. Sofmedia, 2009)

C.S.T. Kansil dan Christine S.T. Pemgantar IlmuHukum Indonesia. Jakarta :PT.RinekaCipta, 2011

Marhaeni Ria Siombo. Hukum Lingkungan dan Pelaksanaan Pembangunan Berkelanjutan di Indonesia. Jakarta: PT. Gramedia Pustaka Utama , 2012

MagdaliaAlfian, "Potensi Kearifan Lokal dalam Pembentukan Jati Diri dan KarakterBangsa”, Makalah dalam Seminar Tentang The 5th Internasional Conference on Indonesian Studies: "Ethnicity and Globalization", diselenggarakanoleh ICSSIS (International Conference \& Summer School on Indonesian Studies) Fakultas Ilmu Pengetahuan Budaya Universitas Indonesia, Yogyakarta, 13-14 Jun 2013

Jurnal Pamel Kritis Konstruktif, L.W.C. van den Berg: Teori Receptio in Complexu, diakses via: https://agendapamel.wordpress.com/isla mic-studies/l-w-c-van-den-berg-teorireceptio-in-complexu/ pada tanggal 18 September 2019

NahiMunkar, Ramai, Khutbah Tentang Tabot Berbau Syiah dan Syirik di Bengkulu, diakses via: https://www.nahimunkar.org/ramaikhutbah-tentang-tabot-berbau-syiah-dansyirik-di-bengkulu/ pada tanggal 18 September 2019

SCRIBD, Teori Receptio in Complexu, diakses via:

https://www.scribd.com/doc/133072606/ Teori-Receptio-in-Complexu pada tanggal 18 September 2019

Skripsi Mustafa Kemal Ramadhan , Implementasi Keterlibatan Masyarakat Dalam Analisis Mengenai Dampak Lingkungan Hidup (Studi Yuridis
Sosiologis Pada Masyarakat Terkena Dampak Di Kota Semarang), Fakultas Hukum Universitas Semarang, 2015, hlm.21 diakses via : http://lib.unnes.ac.id/22148/1/811141123 7-s.pdf pada tanggal 18 September 2019

Wikipedia Ensiklopedia Bebas, Tabot, diakses via: https://ms.wikipedia.org/wiki/Tabot pada tanggal 18 September 2019 